\title{
Ismertetés: A diákok középpontba helyezése: Teljes iskola, teljes közösség, teljes gyermek modell
}

\author{
Placing Students at the Center: The Whole School, \\ Whole Community, Whole Child Model
}

Ismerteti: Járomi Éva $\square$

Országos Közegészségügyi Intézet

Szerzők: Morse LL, Allensworth DD.

Megjelenés: J Sch Health. 2015 Nov; 85(11): 785-794. Published online 2015 Oct 6.

doi: 10.1111/josh.12313

Beküldve: 2018. 02. 14.

doi: 10.24365/ef.v59i3.231

Kulcsszavak: tanulóközpontú; tanulmányi eredmények; egészségügyi mutatók; ifjúsági-felnőtt partnerségek; ifjúság képessé tevése; ifjúsági szerepvállalás; Teljes iskola, teljes közösség, teljes gyermek modell

Keywords: student-centered; educational outcomes; health outcomes; youth-adult partnerships; youth empowerment; youth engagement; Whole School, Whole Community, Whole Child (WSCC) model

\section{HÁTTÉR}

A legtöbb oktatási reform erőfeszítései az Amerikai Egyesült Államokban (és többnyire hazánkban is) a tantervre, az oktatásra és az értékelésre összpontosítanak.

A hangsúlyt - a tanulók eredményességének felelősségét - az iskola vezetésére és a pedagógusokra helyezik. Kevés figyelmet kapnak azonban a tanulók mint fogyasztók, végfelhasználók, akikre leginkább az oktatáspolitika és az oktatási gyakorlat van hatással.
A Teljes iskola, teljes közösség, teljes gyermek elnevezésü modell (Whole School, Whole Community, Whole Child Model, továbbiakban WSCC-modell) elterjesztése, amely a hagyományos Koordinált iskolai egészség és teljes gyermek keretrendszer elemeire, valamint azok kombinálására alapul, lehetőséget nyújt a diákközpontú megközelítés hangsúlyozására és előmozdítására az iskolákban.

A WSCC-modell a koordinált iskolai egészségmodell ${ }^{1} 10$ eleme köré helyezi az öt elemből álló, a teljes gyermeket középpontba helyező megközelítést (Whole Child Framework). ${ }^{2}$ Ez a megközelítés a kívánt eredményeket minden K-12 tanulói számára

' K-12 tanuló: Az amerikai és a kanadai oktatási rendszerben gyakran használják a K-12 terminológiát, amely az összes általános és középfokú oktatási szintet magában foglalja, az óvodától egészen a középiskola 12. évfolyamáig bezárólag: általános iskola (K-5), középiskola első ún „middle school” (6-8) és második része ún. high school (9-12). (Corsi-Bunker: Guide To The Education System In The United States, International Student and Scholar Services, University of minnesota https://isss.umn.edu/publications/USEducation/2.pdf) 
közvetíti. Hozzájárulnak a tanulmányi eredményekhez és végül a magas színvonalú, egészséges, produktív élethez. A WSCC-modell egészét a közösség veszi körül, ezáltal hangsúlyozva, hogy a közösség támogatása nélkül az iskolák nem képesek elérni a fenti célokat. Visszafejtve ezeket a rétegeket, a tanulók képezik a modell legfontosabb, központi elemét [1. ábra].

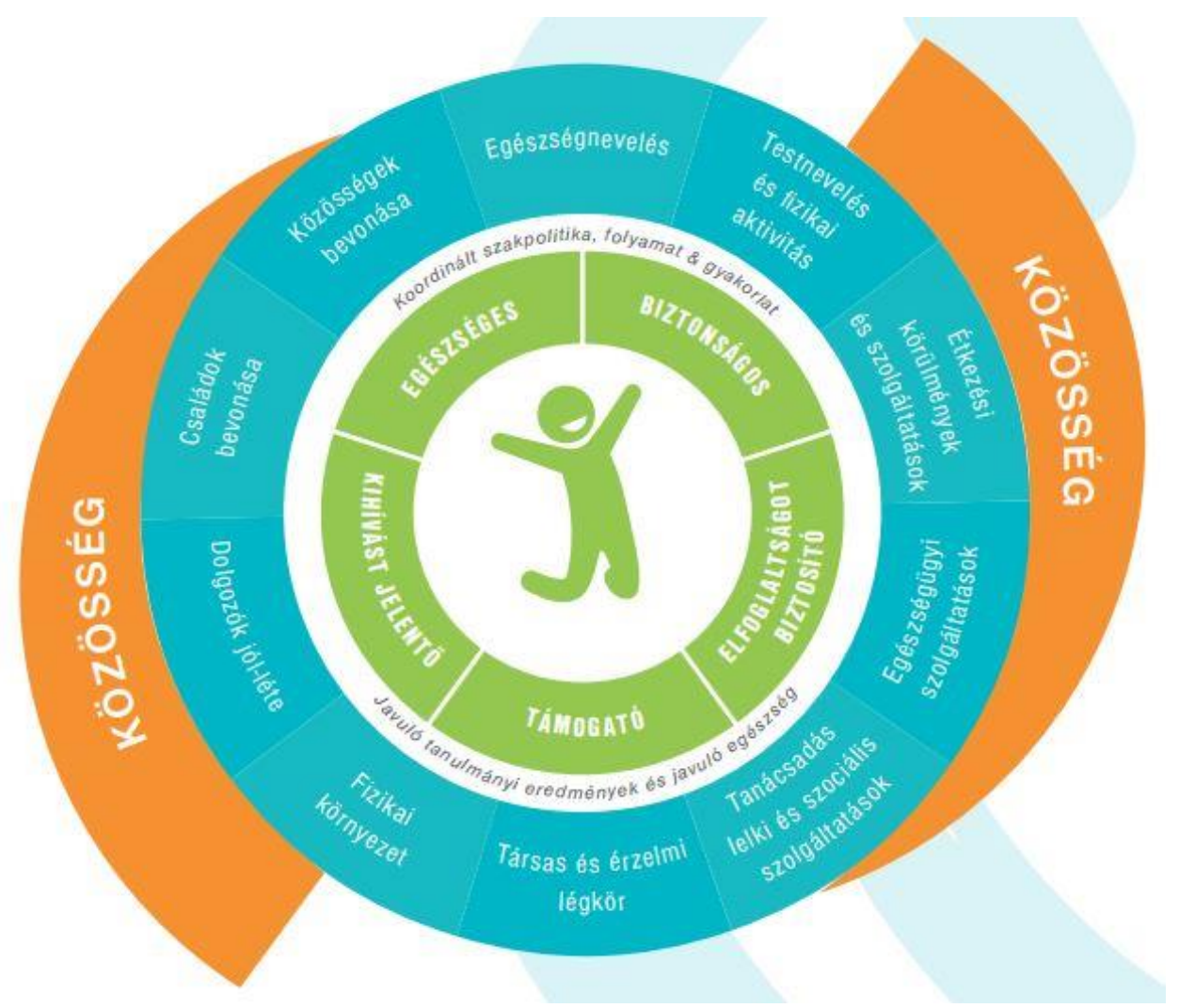

Forrás: Teljes körű iskolai egészségfejlesztési koncepció, TÁMOP-6.1.2.A-14/1-2014-0001, NEFI, 2015

Morse és munkatársainak közleménye egy olyan diákközpontú modellre hívja fel a figyelmet, amely szerint a diákoknak nemcsak a szolgáltatások igénybe vevőinek kell lenniük egészségük, stabilitásuk, elkötelezettségük, támogatottságuk és kihívást jelentő tanulmányaik biztosítása érdekében, hanem - a WSCC-modell megvalósításának keretében - az iskola vezetőinek teljes jogú partnereivé kell válniuk.

A teljes gyermeket középpontba állító kezdeményezés segít a pedagógiai diskurzust elmozdítani az iskolai eredmények egyedüli fókuszáról a gyermekek hosszú távú fejlődésére és sikerére, mindezt oly módon, hogy minden tanuló számára biztosítsák azokat az alapvető erőforrásokat, amelyekre szükség van a siker eléréséhez. A frissített, korszerűsített WSCC-megközelítés ötvözi a 10 komponensből álló koordinált iskolai egészségügyi modellt, valamint az alábbi dimenziókból álló eredeti teljesgyermek-megközelítést a WSCCmodellbe ágyazva:

- Minden tanuló egészségesen lép be az iskolába, és tanulja, valamint gyakorolja is az egészséges életmódot.

- Minden tanuló olyan környezetben tanul, amely a diákok és a felnőttek számára fizikailag és érzelmileg egyaránt biztonságos.

- Minden tanuló aktívan részt vesz a tanulásban, kötődik az iskolához és a tágabb közösséghez. 
- Minden tanuló hozzáfér a személyre szabott tananyaghoz, és részesül a képzett, gondoskodó felnőttek támogatásában.

- Minden tanuló kihívást jelentő tanításban részesül, és felkészült a sikerre, a főiskolára vagy a további tanulmányaira, a munkahelyre, valamint a teljes környezetben való részvételre.

A WSCC-modell célja, hogy megváltoztassák az egészség és az oktatás kereszteződésének útját, és támogassák a diákok egészségét és teljesítményét, eredményességét. A körültekintő tervezés következtében a modell a tanulót helyezi a változás középpontjába. A változáshoz szükséges tényezők pedig magukban foglalják azokat a személyeket is, akiknek tekintélyük van és tisztelet övezi őket, akik a szükséges változásokat (a heterogenitást) elindítják és koordinálják, valamint a kortársakat, akik hangot adnak egy különleges változás szükségességének (homogenitás).

A tanulóközpontú iskolák tudomásul veszik, elismerik a tanulók kritikus közremúködését, akik képesek az önálló tanulásra és a jóllétük biztosítására. A tanulók a változás ügynökeivé és az iskolai fejlesztések szövetségeseivé válhatnak, ha az iskolák hiteles kapcsolatokat hoznak létre és ápolnak velük, ahol a tanulókat alapvetően saját tanulmányi sikereik legitim közremúködőinek, a változás katalizátorainak tartják.

\section{A TANULÓK KÖZPONTBA HELYEZÉSÉNEK LEHETŐSÉGEI}

Az (amerikai) oktatási reform vezetője, Michael Fullan megfigyelése szerint: „Amikor a felnőttek a tanulókról gondolkodnak, a változás potenciális haszonélvezőiként tekintenek rájuk... ritkán tekintik őket az iskolai változások és a szervezeti élet résztvevőinek." "3 Fullan továbbá azt is kijelenti, hogy az iskolában a siker kulcsa a tanulók szívének és elméjének bevonása, elkötelezése, de számos iskola a diákokra csupán érdekes és használható adatok forrásaként tekint. A diákok gyakran olyan közös egyeztetésekre történő meghívásoknak tesznek eleget, amelyek témáit nem érzik fontosnak, ahol olyan nyelvet használnak velük szemben, amelyet korlátozónak, idegennek vagy atyáskodónak, leereszkedőnek tartanak, és ez csupán ritkán eredményez olyan cselekvést vagy párbeszédet, amely valóban befolyásolja az életüket. Értékes és reális ötleteik bemutatása ellenére a tanulók hangja, véleménye nem terjedt el széles körben, így meglehetősen kiaknázatlan erőforrást jelentenek. További értekezése szerint "a tanulók részvételét célzó stratégiáknak minden tanulót el kell érniük, azokat, akik ugyan 'rendben vannak', de untatja őket az iskola irrelevanciája és azokat is, akik hátrányos helyzetüek és az iskolát egyre inkább elidegenitönek találják, ahogy egyre magasabb évfolyamba lépnek"3.

Az ifjúsági kortárs-mediációs programok hatásosságát vizsgáló tanulmányok, amelyekben a diákokat képessé teszik arra, hogy megosszák a felelősséget a minden szempontból biztonságos iskolai környezet megteremtése érdekében, demonstrálták a diákok egyenrangú partnerekként történő kezelésének értékét. A diákok megtanulták a kortársmediációs készségeket, aminek hatására csökkent a felfüggesztések száma, és többek között javult az iskolai légkör is. A kutatás emellett azt is kimutatta, hogy a kortársoktatók hasonló vagy jobb eredményeket értek el, mint a felnőtt oktatók.

Egy további áttekintő közlemény ${ }^{4}$, amely a diákok véleményének hatását vizsgálta az iskolai döntéshozatali folyamatra, azt találta, hogy a tanulók véleményének figyelembevétele mérsékelten pozitív hatással volt a tanulók életkészségeire, demokratikus készségeire, a társadalomban betöltött szerepére, teljes jogú tagságára, a felnőttek (tanárok, iskolai személyzet) és a tanulók közötti kapcsolatokra és az iskolai etikára, míg negatív hatására kevés bizonyítékot talált. Wallerstein, ${ }^{5}$ aki támogatta az ifjúsági szerepvállalási stratégiák alkalmazását az egészségfejlesztés minden területén, megjegyezte, hogy a diákok részvétele fokozza az önismeret és a szociális eredmények, a szocializáció elérését, javítja a mentális egészséget és az iskolai teljesítményt, csökkenti az iskolai lemorzsolódás mértékét, a bűnözést és a szerhasználatot.

Egy 2014-ben közölt, 26 közleményt áttekintő tanulmány azt vizsgálta, hogy milyen hatása van a diákok részvételének az iskolai egészségfejlesztési intézkedések tervezésében, megvalósításában és/vagy értékelésében. Meggyőző bizonyítékot talált: 1. a tanulók énhatékonysága fokozódott (motiváció növekedése, pozitív irányú attitűd-, készség-, kompetencia- és ismeretváltozás); 
2. javult az iskolai légkör; 3. megnövekedtek az interakciók és a társas kapcsolatok, mind a kortársak, mind pedig a diákok és a felnőttek körében.

Azokban az iskolákban tehát, amelyek a változás vezetőiként próbálták meg bevonni a diákokat, figyelemre méltó sikert értek el. A fiatalok bevonásának különböző formái léteznek úgy mint a kortársoktatás, kortárs-mentorálás, ifjúsági akciók, tanulói hang (vélemény), közösségi szolgálat, szolgáltatástanulás, ifjúsági szervezés, állampolgári szerepvállalás és ifjúsági-felnőtt partnerségek, amelyek biztosítják a diákok számára a biztonságérzetet, a valahová tartozás érzését és a hatásosságot; a társadalompolitikai tudatosság és a polgári kompetencia terén szerzett előnyöket; megerősödött közösségi kapcsolatokat, valamint a javuló (tanulmányi) eredményeket.

Tekintettel annak lehetőségére, hogy a tanulók felfedezhetik az igazi elköteleződésüket, a tanulók elfogadják és teljesítik is ezt a fajta kihívást. Zak Malamed és néhány barátja, középiskolai tanulók, úgy döntöttek, hogy ideje megszólaltatni a diákokat. Így megtartották első „Twitter-csevegésüket” a diákok számára, azonban csalódottak voltak amiatt, hogy a diákok keveset mondtak az iskolai reformmal kapcsolatos egyeztetésekről. ${ }^{6} \mathrm{~A}$ diákokhoz intézett kérdés a következőképpen hangzott: "Mit tehetünk az iskola javítása érdekében?" Ez számos frusztrált tanuló lendületétől egészen a Student Voiceii néven ismert szervezetig az oktatás megreformálásának mozgalmává nőtte ki magát a diákok véleményén és cselekedetein keresztül. A támogatók ígéretet tettek arra, hogy segítik a diákok azon törekvéseit, hogy az oktatás hivatalos partnerei legyenek, és biztosítják, hogy a tanulók a saját életüket érintő döntésekre valódi befolyással bírjanak.

A Diákok hangja elnevezésű együttmúködést (Student Voice Collaboration) a New York-i oktatási minisztérium indította el, hogy segítse a tanulók önfejlesztését és az iskolájuk fejlesztését. A részt vevő diákok megtanulták, hogyan múködik az oktatási rendszer, megkérdezték az iskolák vezetőit a döntéshozatalról, és létrehoztak egy térképet, amely bemutatja, hogy milyen döntések születtek az iskolájukban. A tanulók kutatást indítottak, hogy azonosítsák, milyen nehézségek vannak az iskolában, valamint létrehoztak egy diákok által vezetett kampányt ezen nehézségek, kihívások kezelésére.
Végül összeállítottak egy programlistát az egész városra kiterjedően, rámutatva arra, hogy melyek azok az intézkedések, amelyek minden New York-i diák számára előnyösek lehetnek. E munka eredményeképpen egy diákcsoport hat ajánlást dolgozott ki, melyeket megosztottak a New York-i oktatásért felelős kancelláriával. A program célja az volt, hogy megmutassa a tanulóknak, hogy képesek megváltoztatni a rendszeren belüli munkafolyamatokat.

\section{Diákközpontú iskolák}

A Stanfordi Esélyteremtő Oktatási Szakpolitika Központ (Stanford Center for Opportunity Policy in Education) leírta, hogy négy kaliforniai diákközpontú középiskola hogyan járult hozzá a tanulók sikereihez. A diákközpontú gyakorlatok szigorúan, gazdagon és releváns módon a diákok szükségleteire koncentráltak. A diákokok olyan tevékenységeket folytattak, amelyek elmélyítették a tanulást és az igényeikre koncentráltak. A személyre szabottság kulcsfontosságú volt, és emellett a tanulók oktatói támogatást kaptak, amely elősegítette a sikereket. A négy iskola mindegyike támogatta a diákok vezetői képességét és autonómiáját a kérdőíves, tanuló által vezetett és együttmúködésen alapuló tanulásban, az osztályteremben és a közösségben egyaránt. Tanácsadási programokat, az ünnepek kultúráit, tanulói hangot, vezetési lehetőségeket, valamint a szülőkhöz és a közösséghez való kapcsolódást beágyazták minden egyes iskolába.

\section{A „Teljes gyermek - 5” című kezdeményezés}

Az America's Promise Alliance állásfoglalása szerint a "Teljes gyermek - 5" címú kezdeményezés (5 - Whole Child Tenets) nagyon hasonlít a tanulók alapvető szükségleteinek leírásához:

- egészséges kezdet,

- biztonságos terek,

- a gyermekek gondozása (támogatott),

- mások segítésének lehetősége (elkötelezett/bevont),

- hatékony oktatás (kihívást jelentő).

Egy 2014-ben végzett felmérés (2014 Quaglia Institute for Student Aspirations' My Voice survey), ${ }^{7}$ etnikai és társadalmi-gazdasági szempontból sokszínű mintából állt: 66314 fő 6-12. évfolyamos

"http://www.studentvoice.org 
tanuló részvételével, amely 234 iskolát képviselt országszerte, célja a diákok tanulmányi motivációját befolyásoló változók mérése és a következő tanulói mintázatok megvizsgálása:

- önértékelés,

- elkötelezettség,

- cél/motiváció,

- társas/kortárs és tanári támogatás.

A felmérés szerzői továbbá megjegyezték, hogy a 2014-es eredmények csupán kismértékű változást mutattak az 2009-es eredményekhez képest. A diákok önértékelése ötször nagyobb valószínűséggel lett tanulmányi szempontból motivált, míg a diákok 45\%-ának alacsony volt az önértékelése. Azok, akik részt vettek, 16-szor nagyobb valószínűséggel voltak tanulmányi szempontból motiváltak, de 40\%-uk arról számolt be, hogy ők nem kerültek bevonásra. A céltudatos diákok 18-szor nagyobb valószínűséggel voltak tanulmányi szempontból motiváltak, azonban 15\%-nak továbbra sem volt célja.

A tanári támogatás 8-szor nagyobb tanulmányi motivációt jelentett, míg a kortársak általi támogatás megnövelte a tanulmányi motiváció időtartamát. A tanulók 39\%-a nem rendelkezett tanári, 56\%-uk pedig kortársi támogatással. Nyilvánvaló, hogy összehangoltabb és együttmúködőbb megközelítésre van szükség a diákok alapvető szükségleteinek kielégítéséhez; például családok, iskolák, közösségek és kortársak bevonására. A WSCCmodell egy olyan mechanizmus lehet, amelyet az iskolák és közösségek alkalmazhatnak a diákok önértékelésének, elkötelezettségük javítására, kortársi támogatás és tanári támogatás terén, mégpedig oly módon, hogy a diákok partnerekké válnak a modell disszeminálásában.

\section{A tanulók bevonása és képessé tevése}

Az ifjúság képessé tevésének tanulási lehetőségei az egyén, a szervezet és a közösség felhatalmazására/képessé tevésére oszthatók fel. Az egyén képessé tevése a fiatalok önmenedzselési készségeinek, a saját életük felett érzett kompetenciaérzésük fejlesztése útján történik, míg a szervezeti képessé tevés olyan iskolákra és közösségi szervezetekre utal, amelyek lehetőséget nyújtanak a diákok képessé tevésére, akárcsak a tanulók szerepvállalásából eredő előnyökre. A közösségi képessé tevés arra utal, hogy helyi, állami és nemzeti szinten biztosítsa a lakosság részvételének lehetőségét, az egyének, szervezetek és a közösségek fejlesztése érdekében. Sikeres ifjúsági-felnőtt partnerségek akkor alakulnak ki, amikor az ifjúság és a felnőttek közötti kapcsolatokat a közös tanítás, tanulás, valamint a cselekvés kölcsönössége jellemzi.

Mit tehetnek az iskolák a diákok képessé tevésére és a diákok "hangjának” támogatására? A szerzők azt javasolják, hogy a Fletcher által meghatározott négy célt ${ }^{8}$ adaptálják az egészség, valamint az iskolai fejlesztés középpontba helyezésével:

- Minden évfolyam, minden tanulóját, minden témában együttmúködő partnerként kell tekinteni az oktatásban, a tanulásban és az iskola vezetésében (annak biztosítása érdekében, hogy megfeleljenek a diákok szükségleteinek).

- Bővítsék a tanulók közös elvárásait, hogy aktív és egyenlő partnerré váljanak az iskolai változtatásokban (ami magában foglalja, hogy az egészségfejlesztő, tanulókat támogató programok és szolgáltatások az iskolai fejlesztések sarokkövét képezik).

- A tanulóknak és a pedagógusoknak fenntartható, érzékeny és szisztematikus megközelítést kell biztosítaniuk minden tanuló részvétele/bevonása érdekében (az iskolai fejlesztésben és az egészségfejlesztésben egyaránt).

- Érvényesítse minden diák tapasztalatait, perspektíváit és ismereteit fenntartható, erőteljes, célirányos iskolaorientált és iskolaiközösségi szerepvállalásaik által!

Számos kutató fogalmazott meg iránymutatást és ajánlást az iskolák és közösségek számára arról, hogy miként lehet ezt a folyamatot elindítani:

- olyan ifjúsági-felnőtt csapatok létrehozásával, amelyek tudatosan kívánják elérni a hoszszú távú társadalmi változásokat;

- megteremtve az egyensúlyt a rövid távú egyéni támogatások szükségessége és a közösségi változások hosszú távú céljai között;

- felismerve és jutalmazva a fiatalok ifjúsági szervezetekben való részvételét;

- szakmai továbbképzések biztosításával a pedagógusok számára, hogy megismerjék az 
ifjúsági szervezetek erejét, annak érdekében, hogy segítsék a fiatalok készségekkel való felruházását;

- a közösségi költségvetés költségvetési tételének előterjesztésével/támogatásával, az ifjúság partnerként való támogatásának elősegítése érdekében, a közösség és az iskolák fejlesztésének keretében;

- több lehetőséget kínálva a fiatalok részvételéhez, hogy a megkapják a támogatást és fokozatosan vállaljanak egyre nagyobb felelősséget, ezáltal tapasztalatokat és készségeket szereznek;

- coachinggal és folyamatos visszajelzéssel a fiatalok és felnőttek számára;

- olyan szervezeti erőforrások biztosításával, mint a költségvetés, a személyzet képzése és a fizikai környezet, mindezt a fiatalok és felnőttek minőségi partnerségének elősegítése érdekében;

- lehetőség biztosításával a felnőttek és a fiatalok számára, hogy kortársaik számára „tükröt tartsanak” és tanuljanak tôlük.

Emellett a közlemény öt további, olyan feltételt határozott meg, amelyek ahhoz szükségesek, hogy kollektív hatást érjenek el minden kérdésben (különös tekintettel az oktatási reformra), amely tanulságos lehet az iskolai közösségek partnerségei számára, amelyek támogatják az ifjúsági szerepvállalást és a képessé tevést. Ezek közé tartozik a közös napirend, a közös mérési rendszerek, az egymást kölcsönösen erősítő tevékenységek, a folyamatos kommunikáció és az ún. „gerinchálózati" támogató funkciók (mint például a partnerek összehívása, a szükségletek felmérése, közös stratégiai terv kidolgozása az erőforrások összehangolására, sikerességi mutatók kiválasztása, valamint az értékelés kialakítása).

\section{AZ ISKOLAI EGÉSZSÉGRE GYAKOROLT HATÁS}

A WSCC-modell a diákokat helyezi a középpontba, mivel a diákok azoknak a programoknak és szolgáltatásoknak a fogyasztói, amelyeket mi, felnőttek nyújtunk számukra. Egy diákközpontú iskola figyelembe veszi a diákok gondolatait és véleményét. Ez azt jelenti, hogy az iskoláknak minden diák véleményét és ötleteit meg kell találniuk, nem csak a diákönkormányzatba megválasztott vagy iskolai vezetőként (el)ismert tanulókét. Ennek a párbeszédnek az általános iskolákban kell kezdetét vennie, amikor a diákok megtanulják, hogyan érveljenek meggyőzően, hogyan támogassák saját egészségüket, biztonságukat, elkötelezettségüket, tanulásukat és tanulmányi kihívásaikat, valamint kortársaikat.

A szerzők szerint ezek a készségek fejleszthetők, finomíthatók és egy átfogó, egymásra épülő iskolát megelőző, az amerikai nemzeti egészségügyi képzési standardokkal összhangban lévő, ún. PreK-12iii egészségügyi oktatási program megvalósításával támogathatók lehetnek.

Az iskolaigazgatóknak rendszeresen be kell vonniuk minden tanulót a különféle helyszíneken - közösségi médiában, felméréseken, városházán - tartott találkozókba és fókuszcsoportokba.

A folyamatos visszacsatolási lehetőségek kulcsfontosságúak a tanulói hang támogatása szempontjából. Abban az intézményben, ahol fontos, hogy az iskola-egészségügyi bizottságban, ill. munkacsoportban diákok is képviseltessék magukat, felkérnek minden tanulót, hogy vegyen részt az iskola egészségpolitikájának kidolgozásában és végrehajtásában, amely fontos az egyeztetés körülményeinek kialakítása érdekében.

Elengedhetetlen, hogy a diákok a kezdetektôl részt vegyenek a beszélgetésben, és ne csupán a döntések meghozatalát követően. A "rendszer" iránti bizalom kiépítése ugyanis kulcsfontosságú a WSCCmodell sikeréhez. Amellett, hogy az iskolák megvalósítják a WSCC-megközelítést, létre kell hozniuk az iskolai egészségpolitikákról, programokról és szolgáltatásokról folyó párbeszédet is, valamint biztosítaniuk kell, hogy a diáktestület megfelelően reprezentált legyen ezeken az egyeztetéseken. Három egyszerú kérdést érdemes feltenni, amely a folyamat szempontjából kulcsfontosságú: Mit gondolnak a diákok a tervezett intézkedésről, programról vagy szolgáltatásról? Hogyan fognak hatni az irányelvek, programok és szolgáltatások az iskola diákjaira? Mit tennének másképp a diákok, ha erre lehetőséget kapnának?

Annak biztosítása, hogy minden diák rendelkezzen a hatékony kommunikációhoz szükséges készségekkel, csak az első lépése egy olyan környezet

\footnotetext{
iii Iskolás kort megelőző képzési forma, amely a gyermek legkorábbi éveiben az alapvető készségek megtanulására épül.
} 
megteremtésének, ahol a diákok biztonságban érzik magukat és támogatásban részesülnek. $\mathrm{A}$ diákok partnerként kezelése a WSCC-modell terjesztésében segíti a bizalom és az elfogadás megteremtését, valamint biztosítja a diákok szükségleteinek kielégítését. Az ASCD cselekvésre ösztönzése ezzel a mondattal kívánja felhívni a figyelmet a WSCCmodell fejlesztésére:

„Egyszerü változást szeretnénk, amely számottevő hatással jár majd: a gyermeket a döntéshozatal középpontjába helyezi és időbeli, térbeli, valamint humán erőforrásokat allokál minden gyermek sikere érdekében."

A tanulók számára kialakított szerepek, úgy mint szövetségesek, döntéshozók, tervezők és legfőképpen a fogyasztói, kedvezményezetti szerep megteremtése biztosítja a számunkra, hogy a fókusz valóban diákközpontú legyen.

\section{ÖSSZEGZÉS}

A diákok elhelyezkedése a WSCC-modell középpontjában láthatóvá teszi a modell tanítás és egészség iránti elkötelezettségét, hogy együtt készüljenek fel a jelenkor tanulóira és kihívásaira és a holnap lehetőségeire. Ezeket a diákok bevonásával és képessé tevésével érhetjük el, valamint akkor, ha értékes partnerként ismerjük el őket a folyamat során.

Fenti megállapításhoz csatlakozik a Ban Ki-moon ENSZ-főtitkár álláspontjával összhangban lévő, a Lancet folyóiratban közölt bizottsági közlemény ${ }^{9}$ is. A közlemény szerint a legerőteljesebb beavat- kozásoknak a serdülők egészsége és jólléte érdekében ágazatközinek, többszintűnek, valamint több alkotóelemmel rendelkezőnek kell lenniük. Emellett a fiatalokat el kell kötelezni és képessé kell tenni arra, hogy részt vegyenek a felelősségvállalásban és a változás elérésében. ${ }^{10}$

A bemutatott iskolai egészségfejlesztési megközelítésről összefoglalóan elmondható, hogy alapvető szemléletmódbeli különbségek és lemaradás figyelhető meg az iskolai egészségfejlesztésben, illetve a köznevelés terén élenjáró országok (USA) és hazánk között. Nemzetközi szinten a szakpolitikai döntéshozásban is megjelenik a komplex rendszerszintű gondolkodás, az iskola mint intézmény komplex adaptív rendszer részeként történő értelme$z_{\text {zése }}{ }^{i v}$. Ezzel szemben hazánkban az oktatási rendszer különálló diszciplínaként, hierachikus módon jelenik meg.

\section{TANULSÁGOK A HAZAI SZAKEMBEREK SZÁMÁRA}

Habár Magyarországon számos előremutató iskolai egészségfejlesztést támogató kezdeményezés van, ezek elszigetelt módon valósulnak meg, vagy csupán meg nem valósuló koncepciók ${ }^{\vee}$ maradnak. Emellett további problémát jelent, hogy nincs törekvés az igazoltan hatásos, korszerű szemléletû beavatkozások kiválasztására és azok megvalósítására. Ezek helyett továbbra is kampányszerü, lényegében ismeretátadásra fókuszáló programok zajlanak. ${ }^{10}$

\footnotetext{
iv Részvételen alapuló, koordinált, a helyi közösségbe ágyazva, integráltan, számos társadalmi szereplő bevonásával, több beavatkozási irányból megközelítve

v Teljes Körű Iskolai Egészségfejlesztési Koncepció. Nemzeti Egészségfejlesztési Intézet, 2015. http://projek-tek.egeszseg.hu/documents/17618/2222750/Teljes+k\%C3\%B6r\%C5\%B1+lskolai+Eg\%C3\%A9szs\%C3\%A9gfej-leszt\%C3\%A9s+Koncepci\%C3\%B3.pdf/9bd631f4-b027-48028cec-3e343f29c5fe?version=1.0 Elérve: 2018. 01. 30.
} 


\section{HIVATKOZÁSOK}

\footnotetext{
${ }^{1}$ Centers for Disease Control and Prevention (CDC). Components of coordinated school health. 2013. http://www.cdc.gov/healthyyouth/cshp/components.htm Elérve: 2018. 01.30.

${ }^{2}$ ASCD. The Learning Compact Redefined: A Call to Action. A Report of the Commission on the Whole Child. Alexandria, VA: ASCD; 2007:19. http://www.ascd.org/ASCD/pdf/Whole\%20Child/WCC\%20Learning\%20Compact.pdf. Elérve: 2018. 01. 30.

${ }^{3}$ Fullan M. The New Meaning of Educational Change. 4th ed. New York, NY: Teachers College Press; 2007:170-187.

${ }^{4}$ Mager U, Nowak P. Effects of student participation in decision making at school. A systematic review and synthesis of empirical research. Educ Res Rev. 2012;7(1):38-61.

${ }^{5}$ Wallerstein N. What is the Evidence on Effectiveness of Empowerment to Improve Health? Health Evidence Network Report. Copenhagen, Denmark: World Health Organization, Regional Office for Europe, Health Evidence Network; 2006. http://www.euro.who.int/Document/E88086.pdf Elérve: 2018. 01. 30.

${ }^{6}$ Korbey H. How can students have more say in school decisions? http://blogs.kqed.org/mindshift/2014/10/howcanstudents-have-more-say-in-school-decisions/ Elérve: 2018. 01. 30.

${ }^{7}$ Quaglia Institute for Student Aspirations. My Voice National Student Report (Grades 6-12) 2014. Portland, ME: Quaglia Institute for Student Aspirations; 2014. http://www.qisa.org/dmsStage/My Voice_2013-2014_National_Report_8_25 Elérve: 2018. 01. 30.

${ }^{8}$ Fletcher A. Meaningful Student Involvement: Guide to Students as Partners in School Change. 2nd ed. Olympia, WA: The Freechild Project; 2005:4. http://www.soundout.org/MSIGuide.pdf Elérve: 2018. 01. 30.

${ }^{9}$ Patton GC et al. Our future: a Lancet commission on adolescent health and wellbeing. The Lancet. 2016;387:24232478.

10 Járomi É. Az iskolai egészségfejlesztés hazai és nemzetközi szemléletének bemutatása. Egészségfejlesztés. 2017;58(1):36-48.
} 